\title{
Daily cycle and body characteristics of mating Litopenaeus vannamei shrimps (Decapoda: Penaeidae) in the wild off southern Sinaloa, Mexico
}

\author{
J.A. Calderón-Pérez ${ }^{1}$, S. Rendón-Rodríguez ${ }^{1} \quad \&$ R. Solís-Ibarra ${ }^{2}$ \\ 1 Instituto de Ciencias del Mar y Limnología, Unidad Académica Mazatlán, Universidad Nacional Autónoma de México, \\ Apdo. Postal 811, Mazatlán 82000, Sinaloa, Mexico, Telephone: (669) 985-28-45; jacalder@ola.icmyl.unam.mx \\ 2 Facultad de Ciencias del Mar, Universidad Autónoma de Sinaloa, Paseo Clausen s/n, Mazatlán 82000, Sinaloa, \\ Mexico, Telephone: (669) 982-86-56
}

Received 23-IX-2005. C Corrected 31-VII-2006. Accepted 15-XI-2006.

\begin{abstract}
Mating behavior has been described for very few species of penaeoid shrimps. We describe some of the environmental conditions under which mating of Litopenaeus vannamei took place in the ocean, as inferred by the presence of attached spermatophores on the thelycum of females, combined with the presence of mature males with empty ampulla terminalis, both evidence of recent copulation. Out of a total of twelve $24 \mathrm{hr}$ samplings on board the research vessel B/O "EL PUMA", one was selected to examine mating. There were four periods of observation. The highest frequency of females with attached spermatophores were found during the daytime whilst the lowest was registered during the night. Females with attached spermatophore were mostly at stages IV and V of ovarian maturity and fell within the $30-50 \mathrm{~mm}$ of C.L. range. Copulating male size ranged between 30 and $40 \mathrm{~mm}$ of C.L. and there was a close relation between the percentage of mating females and males. Male to female ratio varied throughout the sampling period but it was never 1:1. The female mean size was, in all cases, bigger than the male mean size. Among the environmental factors, salinity and oxygen varied very slightly throughout the sampling period; temperature variation was more pronounced and those changes were attributed to the tidal oscillation. Rev. Biol. Trop. 55 (1): 189-198. Epub 2007 March. 31.
\end{abstract}

Key words: Litopenaeus vannamei, diel reproduction, mating conditions, Gulf of California.

One of the topics regarding the reproductive biology of penaeoid shrimps which has received relatively little attention is copulation. Mating behavior has been described for very few species such as Sicyonia dorsalis (Bauer 1992), Marsupenaeus japonicus (Hudinaga 1942), Litopenaeus stylirostris (AQUACOP 1979), Penaeus monodon (Primavera 1984), Farfantepenaeus paulensis (Brisson 1985) F. brasiliensis (Brisson 1986), L. vannamei (Yano et al. 1988, Misamore and Browdy 1996) L. setiferus (Misamore and Browdy 1996). Naturally, all of these observations have been made under laboratory conditions, since actual observation in the wild would impose many technical difficulties.
Likewise, milieu conditions at mating, have also been studied under captivity conditions; Robertson et al. (1991) reported that $L$. stylirostris matures and mates more readily at the $27-29{ }^{\circ} \mathrm{C}$ temperature range, although they observed that albeit rare, it may also mate at $20{ }^{\circ} \mathrm{C}$. Yano et al. 1988 described the mating of L. vannamei, and the prevailing conditions, mainly temperature range, light regime, light intensity, sex ratio and ovarian development; salinity was not specifically mentioned although it was referred to as filtered seawater; Ogle (1991) performing a survey on the prevailing conditions in shrimp hatcheries, found out that most laboratories kept their brood stock at temperatures between 27 and $29^{\circ} \mathrm{C}$, 
and salinities between 28 and $32 \%$ for maturing and mating purposes.

The aim of this paper is to contribute to the knowledge on penaeoid shrimps reproduction and to describe some of the environmental conditions under which mating of Litopenaeus vannamei took place in the ocean, as inferred by the presence of attached spermatophores on the thelycum of females combined with the presence of mature males with empty ampulla terminalis, both evidence of recent copulation (Yano et al. 1988).

\section{MATERIAL AND METHODS}

Out of a total of twelve nictemeral samplings on board the $50 \mathrm{~m}$ long Research vessel B/O "EL PUMA" (BIOCAPESS Project), at a location off the southern coast of Sinaloa, Mexico (2304'18' $\mathrm{N}$ and $106^{\circ} 19^{\prime} 6^{\prime \prime} \mathrm{W}$ ) one was selected, that of 29-30 June 1992 (new moon phase) because of the occurrence, by far, of the highest numbers of individuals showing signs of recent mating. The parameters registered by means of a CTD were temperature, salinity, oxygen and depth. Oxygen was also determined by Winkler's method with three replicates performed at three levels in the water column. Shrimps were collected by means of a commercial net similar to those used by shrimp trawlers $(22.9 \mathrm{~m}$ head line, with a progressively reducing mesh size from $6.4 \mathrm{~cm}$ on the body to $3.8 \mathrm{~cm}$ at the cod end). Sampling was scheduled for approximately every $6 \mathrm{hr}$. Upon hauling, after about $1 \mathrm{hr}$ trawling at an average speed of $4.5 \mathrm{~km} / \mathrm{hr}$, shrimps were sorted from the catch, identified, sexed and frozen at $-10^{\circ}$ $\mathrm{C}$ for further study; special care was given to females with spermatophores on the thelycum. In the laboratory, carapace length of specimens was measured from the orbital margin to the posterior edge of the same using digital calipers to the nearest $0.05 \mathrm{~mm}$ and the weight of individuals was determined to the nearest $0.1 \mathrm{~g}$. Dissection of the gonadic area allowed the visual estimate of the ovarian maturation without resorting to microscopical sectioning, following the criterion of King (1948), Tuma (1967), Croccos and Kerr (1983), Dall et al. (1990), who, for convenience, have divided the maturation process into five stages, i.e., I, immature (ovarian lobes translucent and smaller in diameter than the gut); II, developing (ovarian lobes opaque, pale yellow-colored and with a diameter similar to that of the gut), III, advanced (Ovarian lobes yellowish and larger in diameter than the gut); IV, fully mature (ovarian lobes occupying entire part of the cepahalothorax cavity, strong lemon yellow color; and V, spawned (lobes flaccid and convoluted with ova remains). Even though there are recent studies in penaeids that combine stages advanced (III) and matured (IV) into one leaving thus four ovarian stages, Palacios et al. 1999, Dumont and D'Incao 2004, other studies also report the utilization of the five stages criterion (Salazar and Gracia 1998). Females were separated in class intervals to determine the size range at which mating was more frequent. Males were examined at the coxa of the fifth pereopod to verify whether they presented ampula terminalis with retained (milk-like colored) or ejected spermatophore (translucent) at a molt stage other than final pre-molting $\mathrm{D}_{2}$ $\mathrm{D}_{4}$ (Ro et al., 1990, Heitzmann et al., 1993; Rendon-Rodriguez, 1996.)

Tide information for the area (Mazatlan) was obtained from prediction tables for 1992 (UNAM, 1991).

\section{RESULTS}

Tidal variation covering the sampling period is shown in Figure 1. Arrows indicate the times when samples were taken. This region is characterized by a mixed predominantly semidiurnal tide regime (Dietrich et al. 1980), both spring and neap tides being of unequal height.

The basic environmental conditions encountered during the sampling period were very close to the optimum values reported on the laboratory or shrimp hatching facilities, Yano et al. 1988, Ogle 1991, Robertson et al. 1991. The narrow temperature and salinity 


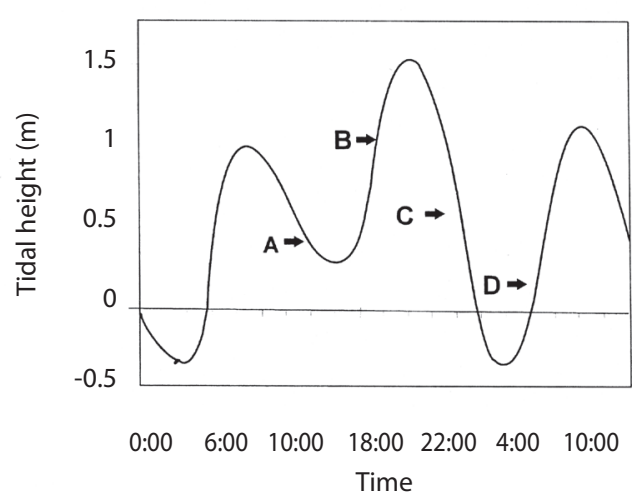

Fig. 1. Tidal variation during the sampling period. Arrows indicate the times when sampling took place.

variations observed near the bottom, were due to the tidal oscillation which has an increasingly noticeable effect the nearer the coast. Oxygen values remained fairly constant, at an optimum level as it was near the saturation value of 4.49 $\mathrm{mg} / \mathrm{l}$ at a temperature of $28^{\circ} \mathrm{C}$ and a salinity of $34.5 \%$ (Green and Carritt 1967).

\section{Temperature and salinity}

Temperature and salinity profiles showed some variation during the sampling period, particularly the former (figure 2, A - D). In all cases, both parameters were higher at the surface than at the bottom (ca. $25 \mathrm{~m}$ ). During the first sampling interval (2A), temperature showed very little variation through the water column with the lowest value at the bottom $\left(29.5{ }^{\circ} \mathrm{C}\right)$. Likewise, salinity changed very little (34.80 and $34.75 \%$ at surface and bottom, respectively). This sampling was made near the end of the ebb tide. During the second sampling period (2B) both parameters showed slight changes in relation to the previous one. Salinity varied from 34.59 to $34.41 \%$ at surface and bottom, respectively. Temperature showed a higher range, from 30.1 to 27.5 ${ }^{\circ} \mathrm{C}$ at surface and bottom, respectively. This sampling took place during the second half of the flood. The third sampling period (2C), produced more pronounced variation in both parameters. Temperature ranged between 29.8 and $27.5{ }^{\circ} \mathrm{C}$ at surface and bottom while salinity varied between 34.59 and $34.42 \%$ likewise. This sampling was taken about mid ebb tide. Finally, the fourth sampling (2D), showed the highest variation of all in temperature which ranged from 29.9 to $25.9{ }^{\circ} \mathrm{C}$ at surface and bottom while the variation in salinity was the same as that of the previous sampling, i.e., between 34.59 and $34.42 \%$. This sample was taken during the first half of the flood.

\section{Oxygen}

\section{Dissolved oxygen} showed very little variation throughout the water column and the sampling periods as the profiles indicate (Fig. 3

Fig. 2 (A-D).- Temperature and salinity profiles during the sampling period; A, 15:00 hr; B, 19:00 hr; C, 01:33 hr; and D, 07:10 hr. 

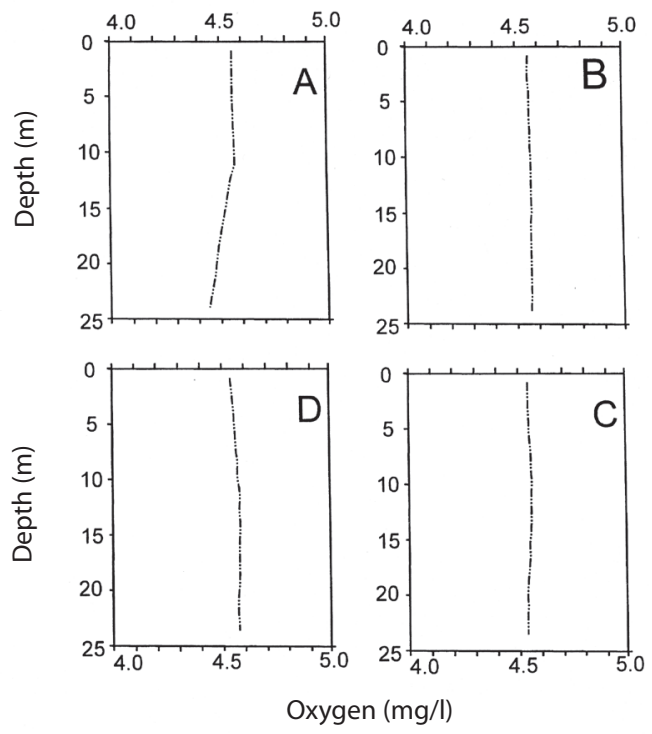

Fig. 3 (A-D).- Oxygen variation during the $24 \mathrm{hr}$ sampling period on the water column. Sampling times of A through D as in Fig. 2.

A - D). In all cases, dissolved oxygen values ranged between 4.4 and $4.6 \mathrm{mg} / \mathrm{l}$.

\section{Sex ratio and size differences}

The total number of shrimps per sampling is given in Table 1. The female/male ratio was, in every case different from the $1: 1$ ratio adopted by most shrimp maturation laboratories (Aquacop 1983, Wyban et al. 1987; Yano et al. 1988, Ogle 1991). The highest ratio (1:2.8) occurred during the second sampling, between 19:02 and 20:02 $\mathrm{hr}$ while the lowest (1:0.5) was observed during the third period, between 01:33 - 2:33 hr The closest to the 1:1 ratios were the first and the fourth sampling periods (1:1.5 between 15:05 - 16:05 hr, and 1:1.3, between 07:10 - 08:10 hr, respectively.

Figure 4 shows that female mean C.L. size was consistently bigger than that of males throughout the sampling period $(\mathrm{t}=18.01>$ $\mathrm{t}_{05 \text { (2) } 300}=1.968$ ), it also shows that during the second sampling, the mean C.L. size of the few females was remarkably lower than that of the three other samplings, but because of the high standard error for that sampling (1.295 compared to $0.3408,0.4883$ and 0.3202 of A, $\mathrm{C}$ and $\mathrm{D}$, respectively) which was due, basically, to the low number of specimens (11), it could not be proved that there was a significant

TABLE 1

Sex proportion and mean weight of $\mathrm{L}$. vannamei shrimp caught during the $24 \mathrm{hr}$ sampling period

$\begin{array}{cccccccc}\begin{array}{c}\text { Time of Day } \\ (\mathrm{hr})\end{array} & \text { Sex } & \begin{array}{c}\text { No. } \\ \text { (Indiv.) }\end{array} & \text { F:M } & \begin{array}{c}\text { Weight } \\ (\mathrm{g})\end{array} & \text { S.D. } & \text { Min. } & \text { Max. } \\ 15: 00 & \text { F } & 65 & 1: 1.5 & 49.6 & 8.2 & 37.3 & 77.4 \\ & \text { M } & 100 & & 38.3 & 5.4 & 30.8 & 62.8 \\ 19: 00 & \text { F } & 11 & 1: 2.8 & 38.7 & 9.3 & 16.1 & 51.9 \\ & \text { M } & 31 & & 38.0 & 2.6 & 33.7 & 41.9 \\ 01: 00 & \text { F } & 42 & 1: 0.5 & 48.2 & 7.4 & 25.6 & 63.7 \\ & \text { M } & 21 & & 40.3 & 3.2 & 34.9 & 47.5 \\ 07: 00 & \text { F } & 61 & 1: 1.2 & 48.8 & 5.9 & 36.6 & 64.2 \\ & \text { M } & 74 & & 40.0 & 4.3 & 28.6 & 50.5 \\ & & & & & & & 77.4 \\ \text { Total } & \text { F } & 179 & 1: 1.3 & 48.2 & 7.9 & 16.1 & 62.75\end{array}$




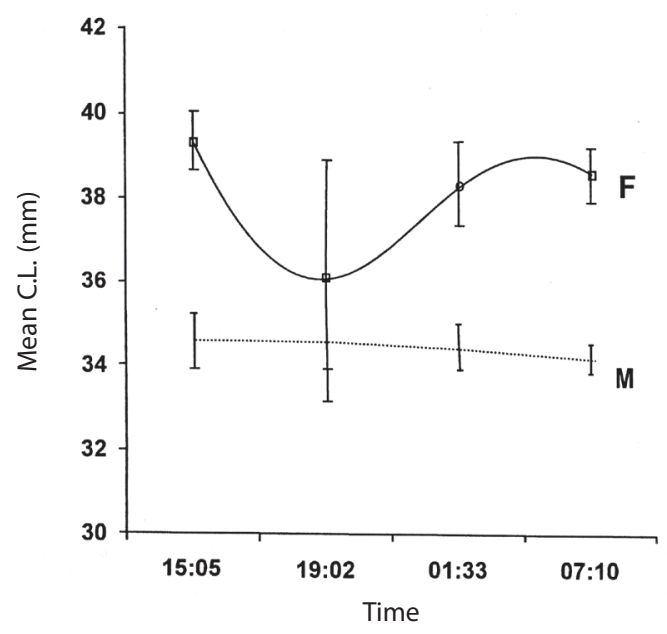

Fig. 4. Comparison of mean C.L. size between male and female L. vannamei.

difference in size among sampling periods at the $95 \%$ confidence level. Males, on the other hand showed a rather uniform C.L. mean size.

\section{Size distribution and gonad development of patched and non-patched females}

Figure 5 (A-D) shows the size distribution of patched and non-patched females caught during the same $24 \mathrm{hr}$ sampling period.

Size ranged from 25.3 to 46.8 $\mathrm{mm}$ of C.L. All the ovarian development stages were present within this range although the prevalent stages were advanced, fully mature, and spawned.

\section{Sampling A.}

This sampling took place in the afternoon, around 15:00 $\mathrm{hr}$, it produced the highest number of females, 57, of which 14 were patched and 43 non-patched. The former were mostly at the mature stage (IV); one advanced (III) and one spent $(\mathrm{V})$. The size of this group ranged from 36.5 to
$46.8 \mathrm{~mm}$ of C.L., mean 40.6. The latter group, the non-patched females, presented a slightly wider size range (33.3 to $46.7 \mathrm{~mm}$ C.L.), mean 38.9 , and most of the ovarian development stages were present within it, although stages III, IV and V were dominant.

\section{Sampling $B$}

I was taken around 19:00 hr produced very few females (14) and none of them were patched. All development stages were present, again dominated by stages III, IV, and V. Size ranged from 25 to $40.6 \mathrm{~mm}$, mean $36.0 \mathrm{~mm}$ C.L.

\section{Sampling $C$}

It was taken around 01:00 hr, produced 39 females of which only 4 were patched and the prevailing ovarian development stage was $\mathrm{V}$ (spent), including the 4 patched ones which fell within a 30.0 to $40.3 \mathrm{~mm}$ range, and a mean $37.11 \mathrm{~mm}$ C.L., whereas the non-patched group fell within the 29.5 to $42.7 \mathrm{~mm}$ range, with a mean of $38.49 \mathrm{~mm}$ C.L.
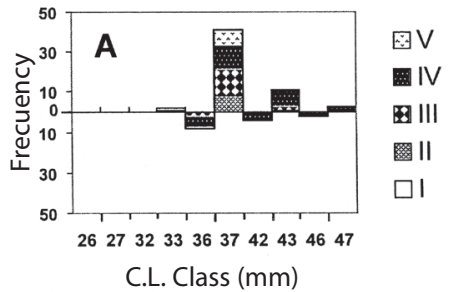

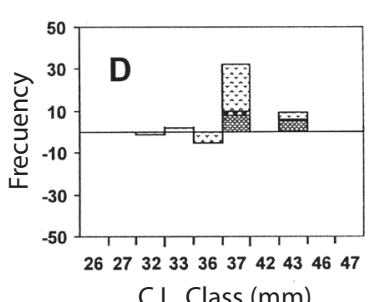

C.L. Class (mm)

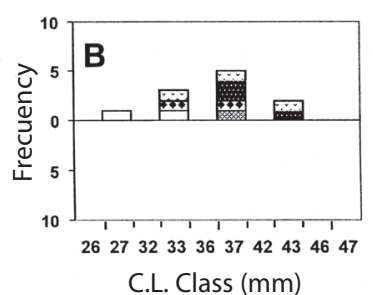

C.L. Class (mm)

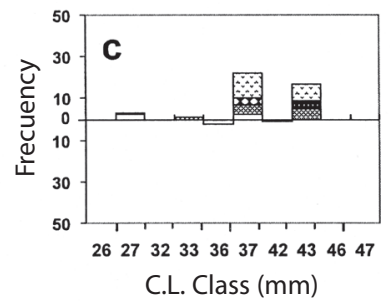

Fig. 5. (A-D). Size distribution of patched and non-patched females, top and bottom halves, respectively, caught during the $24 \mathrm{hr}$ sampling period. Ovarian development is also shown at each C.L. interval. Times of A through D as in Fig. 2. 
Sampling $D$

It took place around 07:00 hr, produced 43 females, 6 of which were patched, all with spent ovaries. Size range of these was 34.2 to $38.2 \mathrm{~mm}$ and a mean of $37.5 \mathrm{~mm}$ C.L. Size range of non-patched females was 33.1 to 44.2 $\mathrm{mm}$ and a mean of $38.7 \mathrm{~mm}$ C.L. More than half of the non-patched individuals (21) had spent ovaries.

To test whether or not there was a significant difference in the number of patched females throughout the sampling period, a Kolgomorov-Smirnov one-sample test (Zar, 1974) was performed and it resulted in a significant difference $\mathrm{D}=0.3587>\mathrm{D}_{23(05)}=$ 0.27490 .

\section{Size distribution of males with either ejected or retained spermatophores}

The size distribution of males with ejected (ES) or retained (RS) spermatophores is shown in Fig. $6(\mathrm{~A}-\mathrm{D})$. The time for each sampling is the same as that of the females.
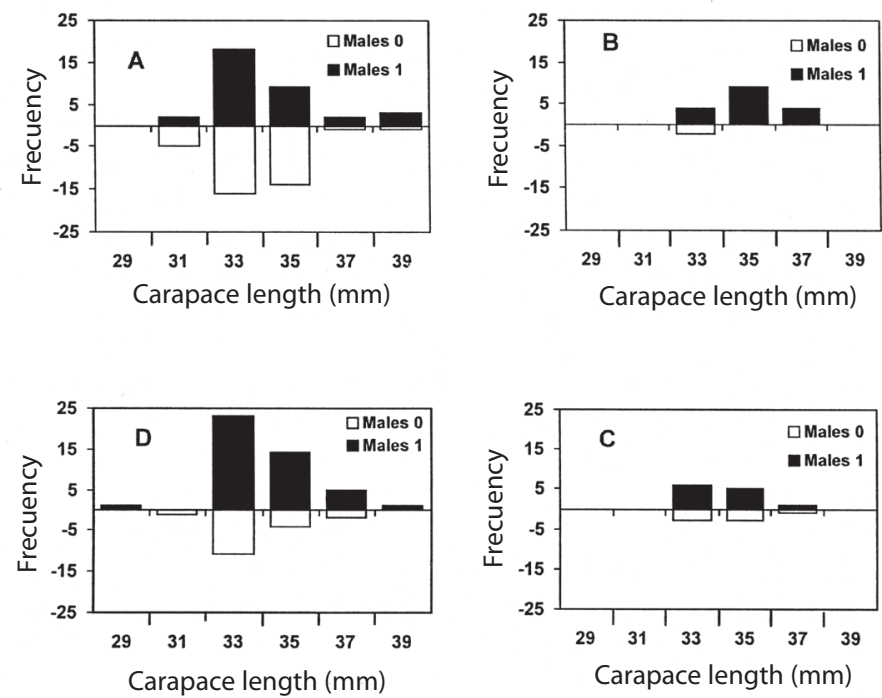

Fig. 6. (A-D). size distribution of males with ejected ( $\square$ ) (ES) and retained ( (RS) spermatophores. Times of A through D as in Fig. 2.

\section{Sampling A}

This sampling produced the highest number of individuals (71) as well as the highest proportion of males with ejected spermatophores $(52 \%)$. The size of these individuals ranged from 31.1 to $38.4 \mathrm{~mm}$ C.L. with a mean of $33.9 \mathrm{~mm}$ C.L.; the size of the 34 individuals with retained spermatophores ranged from 31.3 to $40.0 \mathrm{~mm}$, with a mean of $34.3 \mathrm{~mm}$ C.L.

\section{Sampling $B$}

It produced a very small number of males (19), and there were only 2 individuals with ejected spermatophores $(10.59 \%)$; their size ranged from 32.6 to $33.8 \mathrm{~mm}$ with a mean of $33.2 \mathrm{~mm}$ C.L.

\section{Sampling $C$}

As in the previous case, it resulted in a low number of males (12 RS, and $7 \mathrm{ES}$ ). The former ranged from 33.1 to $36.9 \mathrm{~mm}$ with a mean of $34.4 \mathrm{~mm}$ C.L. while the latter varied from 33.0 to $36.14 \mathrm{~mm}$ and a mean of $34.36 \mathrm{~mm}$ C.L.

\section{Sampling D}

The final sampling produced a relatively high number of males (44 RS and 18 ES). RS individuals ranged from 29.13 to $38.44 \mathrm{~mm}$ C.L. with a mean of $34.2 \mathrm{~mm}$ while the latter ranged from 31.9 to $36.3 \mathrm{~mm}$ C.L. with a mean of $34.0 \mathrm{~mm}$.

Again, as for the femlaes, to test whether or not there was a significant difference in the number of males with ejected spermatophores throughout the sampling period, a Kolgomorov-Smirnov 
one-sample test (Zar, 1974) was performed and it resulted in a significant difference $\mathrm{D}=0.3281$ $>\mathrm{D}_{23(05)}=0.27490$.

\section{Proportion of sexually active females and males}

The proportion of sexually active shrimps seems to be closely related throughout the sampling period as shown in Fig. 7 (A and B). The top figure (A) shows that the proportions of male shrimps without spermatophores are always higher than the females with attached spermatophores; i.e., sampling A, 52.0 vs. 24.5 $\%$; sampling B, 10.5 vs $0 \%$; sampling C, 36.8 vs. $10.5 \%$; and sampling D, 29.0 vs. $13.9 \%$.
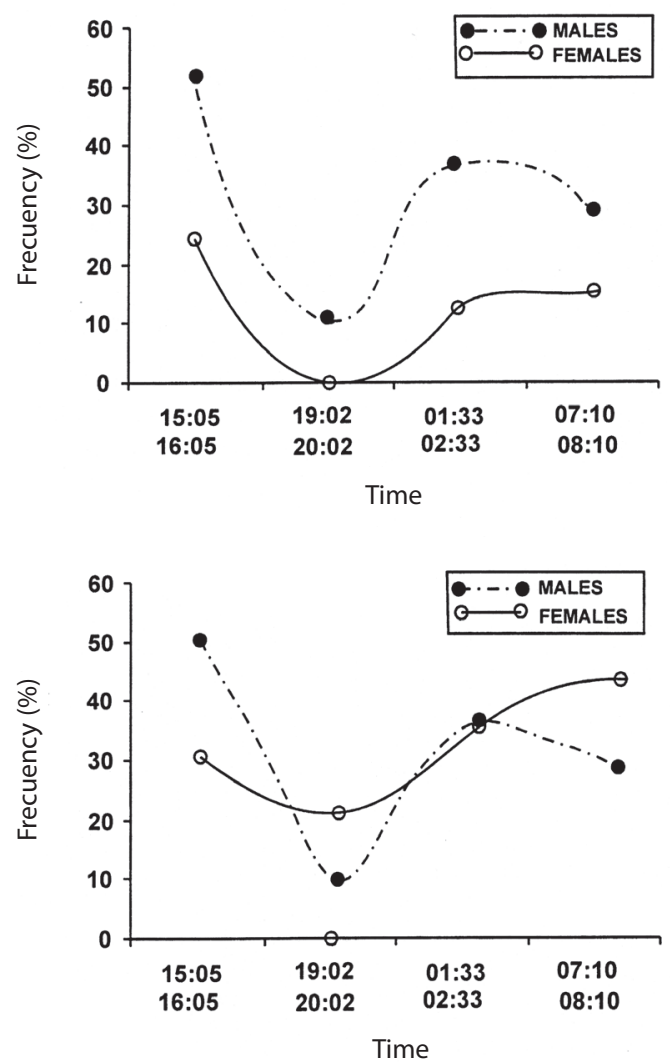

Fig. 7. (A-B).- Proportion of sexually active male and female $L$. vannamei individuals. In A, only females with attached spermatophores are considered; in B, females with attached spermatophores plus those with spent ovaries are taken into account.
However, if spent females (stage $\mathrm{V}$ ovaries) are taken into consideration, the proportions change; i.e., A, 50.7 vs. $30.5 \%$; B, 10.5 vs. $21.4 \%, C, 36.8$ vs. 35.8 ; and D, 29.0 vs. 43.4 , as shown in figure 7 (B).

\section{DISCUSSION}

Even though the conditions under which mating took place could not be established precisely, as they varied throughout the sampling period because of the tidal currents, and the specimens may have copulated anytime between two hours and a few minutes before they were caught, as reported by Yano et al. 1988 , it is clear though that the range of the parameters differ very slightly from those employed in the maturing and hatching facilities, Yano et al. 1988, Ogle 1991, Robertson et al. 1991, which may indicate that when temperature, salinity and oxygen fall within those ranges in the ocean one can expect mating to take place in L. vannamei.

The different female:male ratios found at different times of the sampling period were probably the result of the small number of specimens in the samples; the differences were higher when the number of individuals was lower. Conversely, when the number of animals in the sample increased, the ratio decreased, therefore, it might be possible that if a large sample is taken, the proportion should approximate the 1:1 ratio although it is not always easy to determine whether this ratio is necessarily the expected one (Wenner, 1972).

In relation to the male-female size that was significantly different, this sexual dimorphism has already been mentioned by different authors, Perez-Farfante, 1988, mentions a maximum total length of $187 \mathrm{~mm}$ in males and $230 \mathrm{~mm}$ in females, while Hendrickx (1996) reports 227 and $178 \mathrm{~mm}$ of total length for females and males, respectively.

The size of females engaged in mating, ranged from 35 to $48 \mathrm{~mm}$ C.L., below that range, the main ovarian stage was immature, although with these limited results, it is not 
possible to assert that this is the minimum mating size, thus, a more comprehensive study is needed to establish this fact. The size of active males was lower than that, very likely, it included the whole size range (29 to $39 \mathrm{~mm}$ C.L.) observed in this study and presumibly even lower as Rendon Rodriguez (1996) reports viable spermatozoa in smaller individuals.

Yano et al. 1988 reported that the spermatophore implantation in females was only successful in mature females. This study, however, shows that although most implantations did take place on females with ripe ovaries, there was one case in which the spermatophore was attached to a female with a stage III ovary. That probably may be due to the difference in behavior between confined and free living individuals as the former may be capable on focusing on the right mating partner whereas in the latter the potential partners are manifold.

With regards to the comparison of females and males engaged in copulation, if only the females with attached spermatophores are taken into account, there will be an underestimation of active females during mating events, therefore, checking the female gonads besides the presence of spermatophores on the thelycum, is not a trivial matter. Thus, the proportions depicted on the lower Figure 7 would seem to be more appropriate since it would be reasonable to assume that spent females have copulated recently, Yano et al. 1988 report that females spawn two hours after copulation and very shortly after that event, the attached spermatophore is shed.

Once the females spawn shortly after mating, the larvae hatch and during a few weeks they undergo a series of developmental stages from nauplius up to the stage of postlarva, when they enter estuarine waters or coastal lagoons (Pearson, 1939). If one examines the abundance of postlarval $L$. vannamei throughout the summer months in coastal areas (Mair et al., 1982, Poli and Calderon-Perez, 1986, Solis-Ibarra et al., 1993) mating and spawning episodes must take place repeatedly along the tropical Eastern Pacific coast. Poli and Calderon, (1985) argue that Litopenaeus species enter these water bodies more successfully just before the onset of the rainy season as the tidal currents are not hindered by the strong continental runoff, thus the postlarval recruitment resulting from successful mating and ensuing spawning in the months of June and July is crucial for these penaeids to settle in these areas, otherwise the postlarvae will remain at sea where conditions are not as advantageous. It would be interesting to find out, though, whether this phenomenon occurs randomly or if the proximity of a coastal lagoon where postlarvae find optimal conditions to grow rapidly, influences significantly the sites where mating and spawning take place, although the physical factors examined in this study, mainly salinity, do not provide any evidence that there is a clear influence of estuarine water. There might be, however, other differences that shrimps are capable of detecting, tannins, for example, or any other chemical clues typical of continental waters, as suggested by Mair et al., (1982). Finally, from observations in captivity, it is generally accepted that mating in L. vannamei takes place just before and after darkness, Yano et al. (1988) Ogle (1991), the results of this study do not support that assertion since the highest proportion of mating individuals was caught around 15:00 hr, thus if we take the $2 \mathrm{hr}$ lapse reported by Yano et al. (1988) as a maximum backward limit, it would mean that mating takes place at or just after the most illuminated time of the day. Here again, it may have been due to the difference in milieu conditions. Since this sampling took place during the new moon phase, it is possible that visibility conditions during the night were inadequate for the partners to find each other so they had to perform the act during the daytime hours. It is clear that more studies are needed to solve this and many other questions that still remain to be answered in relation to this topic.

\section{ACKNOWLEDGMENTS}

The authors express their appreciation to the skipper and crew of the B/O "EL PUMA" for their help during the cruises from which 
this work originated. Thanks are also due to the students who participated in the sampling program BIOCAPESS and gave their time generously. This study was supported by funds from the National Autonomous University of Mexico (UNAM).

\section{RESUMEN}

Estudiamos el apareamiento del camarón Litopenaeus vannamei . La mayoría de las hembras con espermatóforos fueron capturadas durante el día y estaban en las etapas IV y V de desarrollo ovárico (longitud $30-50 \mathrm{~mm}$. Los machos apareados midieron entre 30 y $40 \mathrm{~mm}$. La proporción sexual varió pero nunca fue 1:1. Las hembras siempre fueron más grandes que los machos. Durante el muestreo, la salinidad y el oxígeno variaron poco. La temperatura varió más y atribuimos estos cambios a las mareas.

Palabras clave: Litopenaeus vannamei, ciclo diario de reproducción, condiciones de apareamiento, Golfo de California.

\section{REFERENCES}

AQUACOP. 1979. Penaeid reared broodstock: closing the cycle on P. monodon, P. stylirostris and P. vannamei. Proc.World Maricult. Soc. 10:445-452.

AQUACOP. 1983. Constitution of broodstock, maturation, spawning, and hatching systems for penaeid shrimps in the Centre Oceneanólogique du Pacifique. In: McVey, J. P. CRC Handbook of Mariculture. Vol. I. Crustacean Aquaculture. CRC, Boca Raton, Florida, USA. 544 p.

Bauer, R.T. 1992. Repetitive copulation and variable success of insemination in the marine shrimp Sicyonia dorsalis (Decapoda: Penaeoidea). J. Crustac. Biol. 12: $153-160$.

Brisson, S. 1985. The mating behavior of Penaeus paulensis Perez-Farfante, 1967 (Decapoda, Penaeidae). Crustaceana 50: 108-110.

Brisson, S. 1986. Observations on the courtship of Penaeus brasiliensis. Aquaculture 53: 75-78.

Croccos, P.J. \& J.D. Kerr, 1983.- Maturation and spawning of the banana prawn Penaeus merguiensis de Man (Crustacea:Penaeidae) in the Gulf of Carpentaria, Australia. J. Exp. Mar. Biol. and Ecol. 69: 37-59.
Dall, W., B.S. Hill, P.C. Rothlisberg \& D.S. Sharples, 1990. The Biology of Penaeidae. J.H.S. Blaxter \& A.J. Southward (Eds.). Adv. Mar. Biol. Vol. 27, 489 p.

Dietrich, G., K. Kalle, W. Krauss \& G. Siedler. 1980. General Oceanography. Wiley Interscience, New York, New York, USA. 626 p.

Dumont, L. F. C. \& F. D'Incao, 2004. Stages of gonadal development in females of «barba-ruça» shrimp (Artemesia longinaris - Decapoda, Penaeidae). Iheringia, Sér. Zool. 94: 389-393.

Green, E.J. \& D.E. Carritt. 1967. New Tables for oxygen saturation of seawater. J. Mar. Res. 25: 140-147.

Heitzmann, J.C., A. Diter \& Aquacop. 1993. Spermatophore formation in the white shrimp, Penaeus vannamei Boone 1931: dependence on the intermolt cycle. Aquaculture 116: 91-98.

Hendrickx, E.M. 1996.- Los Camarones Penaeodiea Bentonicos (Crustacea: Decapoda: Dendrobranchiata) del Pacifico Mexicano. CONABIO-ICMYL, UNAM, México DF, México. 147 pp.

Hudinaga, M. 1942. Reproduction, development and rearing of Penaeus japonicus. Japan. J. Zool. 10: 305393.

King, J. E. 1948. A study of the reproductive organs of the common marine shrimp, Penaeus setiferus (Linnaeus). Biol. Bull. 94: 244-262.

Mair, McD.J., J.L. Watkins \& D.I. Williamson. 1982. Factors affecting the immigration of postlarval penaeid shrimp into a Mexican lagoon system. Oceanologica Acta No.Sp. Proceedings International Symposium on Coastal lagoons, SCOR/IABO/UNESCO, Bordeaux, France, 8-14 September, 1981, p. 339-345.

Misamore M.J. \& C.L. Browdy. 1996. Mating behaviour in the white shrimps Penaeus setiferus and P. vannamei: a generalized model for mating in Penaeus. J. Crustac. Biol. 16: 61-70.

Ogle, J.T. 1991. Maturation of Penaeus vannamei based upon a survey. Gulf. Res. Rep. 8: 295-297.

Palacios, E.; C. Rodríguez-Jaramillo \& I.S. Racota, 1999. Comparison of ovary histology between differentsized wild and pond-reared shrimp Litopenaeus vannamei (=Penaeus vannamei). Invert. Reprod. Develop. 35: 251-259.

Pearson, J.C. 1939.- The early life histories of some American Penaeidae, chiefly the commercial shrimp Penaeus setiferus (Linn.), Bull. Bur. Fish. Wash. 49: $1-73$. 
Perez-Farfante, I.., 1988. Illustrated Key to Penaeoid Shrimps of Commerce in the Americas. NOAA Technical Report NMFS 64, U.S. Department of Commerce, Washington, DC. 32 p.

Poli, C.R. \& J.A. Calderon-Perez, 1987. Efecto de los cambios hidrologicos en la boca del rio Baluarte sobre la inmigracion de postlarvas de Penaeus vannamei Boone y $P$. stylirostris Stimpson al sistema lagunar Huizache-Caimanero, Sinaloa, Mexico (Crustacea: Decapoda:Penaeidae). An. Inst. Cienc. Del Mar y Limnol. Univ. Nal. Autón. México 14: 29-44.

Primavera, J. H. 1984. A review of maturation and reproduction in closed thelycum penaeids. Proceedings of the First Internacional Conference on the Culture of Penaeid Prawns Shrimps1984. 1983 SEAFDEC Aquaculture Department. Pp 47-64, Iloilo City, Philippines.

Rendon-Rodriguez, S. 1996. El potencial reproductor, algunas características del tracto reproductivo y su relación con la muda en machos adultos del camarón blanco, Penaeus vannamei Boone 1931 (Decapoda: Penaeidae). M.Sc. Thesis. UACPyP, CCH, UNAM, México, DF. 131 p.

Ro, S., P. Talbot, J.Leung-Trujillo, \& A.L. Lawrence. 1990. Structure and function of the vas deferens in the shrimp Penaeus setiferus: segments 1-3. J. Crustac. Biol. 10: 455-468.
Robertson, L., W. Bray, \& A. Lawrence. 1991.Reproductive response of Penaeus stylirostris to temperature manipulation. J. World Aquacult. Soc. 22: $109-117$

Solis-Ibarra, R., J.A. Calderon-Perez \& S. RendonRodriguez, 1993. Abundancia de postlarvas de camaron blanco Penaeus vannamei (Decapoda:Penaeidae) en el litoral del Sur de Sinaloa, México, 1984-85. Rev. Biol. Trop. 41: 573-578.

Tuma, D. J. 1967. A description of the development of primary and secondary sexual characters in the banana prawn, Penaeus merguensis de Man (Crustacea: Decapoda: Penaeinae). Aust. J. Mar. Freshwat. Res. 18: $73-88$.

U.N.A.M. 1991. Tablas de Predicción de Mareas 1992. Puertos del Pacífico. Inst. Geofís. Servicio Mareográfico, Serie A Oceanografía. U.N.A.M. pp. 259-271.

Wenner, A.M. 1972.- Sex ratio as a function of size in marine Crustacea. Am. Nat. 106: 321-350.

Wyban, J.A., C.S. Lee, J.N. Sweeney \& W.R. Richards. 1987. Observations on development of a maturation system for Penaeus vannamei. J. World Aquacult. Soc. 18: 198-200.

Yano, I., R.A. Kanna, R.N. Oyama \& J.A. Wyban. 1988. Mating behaviour in the penaeid shrimp Penaeus vannamei. Mar. Biol. 97: 171-175. 